avoided. Our one experience with direct fetal treatment was not successful, and possibly a longer duration of transplacental treatment would have been more appropriate.

In our series the Wolff-Parkinson-White syndrome as the underlying cause of the tachycardia was found in three of the 22 infants who had a postnatal electrocardiogram.

In summary $\mathrm{p}_{\boldsymbol{c}}$,hological atrial tachycardias are a potential cause of non-immune hydrops. As these rhythm disturbances may be intermittent, this diagnosis should be considered in all cases of fetal hydrops even if the tachycardia is not present at the initial examination. It is not possible to predict which of the non-hydropic fetuses will progress to become hydropic. We therefore believe that an attempt at transplacental treatment is valid in all cases. Our results show that maternal transplacental treatment is both safe and effective and may avert preterm delivery and its attendant morbidity.

DJM was on secondment from University College Hospital. LDA and DCC were supported by the British Heart Foundation and MJT by the British Heart Foundation and the Joseph Levy Foundation.
1 Siber DL, Durnin RE. Intrauterine atrial tachycardia. Am f Dis Child 1969;117:722-6.

2 Hedvall G. Congenital paroxysmal tachycardia-a report of three cases. Acta Paediatr Scand 1973;62:550-2.

3 Allan LD, Anderson RH, Sullivan ID, Campbell S, Holt DW, Tynan M Evaluation of fetal arrhythmias by echocardiography. Br Hearl $\mathcal{f} 1983 ; 50$ Evalua

4 Kleinman CS, Donnerstein RL, Jaffe CC, et al. Fetal echocardiography. A tool for the evaluation of in utero cardiac arrhythmias and the monitoring of in utero therapy: analysis of 71 patients. Am $\mathcal{F}$ Cardiol 1983;51:237-43.

5 Silverman NH, Enderlein MA, Stanger P, Teitel DF, Heymann MA, Golbus MS. Recognition of fetal arrhythmias by echocardiography. Journal of Clinical Ultrasound 1985;13:255-63.

6 Dumesic AD, Silverman NH, Tobias S, Golbus MS. Transplacental cardioversion of fetal supraventricular tachycardia with procainamide. $N$ Engl $\mathcal{F}$ Med 1982;37:1128-31.

7 Spinnato JA, Shaver DC, Flinn GS, Sibai BM, Watson DL, Martin-Carcia J. Fetal supraventricular tachycardia: in utero therapy with digoxin and Fetal supraventricular tachycardia: in utero therapy with
quinidine. foumal of Obstetrics and Gynecology 1984;64:730-5.

8 Wladimiroff JW, Stewart PA. Treatment of fetal cardiac arrhythmias. $\mathrm{Br}$ J Hosp Med 1985;9: 134-40.

9 Allan LD, Crawford DC, Anderson RH, Tynan M. Echocardiographic and anatomical correlates in fetal congenital heart disease. Br Heart $\mathrm{f}$ 1984;52: $542-8$

10 Shenker L. Fetal cardiac arrhythmias. Obstet Gynecol Surv 1979;34:8, 561-72. 1 Kleinman CS, Copel JA, Weinstein EM, Santulli TV, Hobbins JC. Treatment of fetal supraventricular tachyarrhythmias. Journal of Clinical Ultrasound 1985;13:265-73.

12 Schreiner RL, Hurwitz RA, Rosenfeld CR, et al. Atrial tachyarrhythmias associated with massive edema in the newborn. $\mathcal{F}$ Perinat Med 1978;6:274-8.

13 Colley N, Talbert DG, Southall DC. Fetal phonocardiography. Biophysical profile in the fetus from a phonographic sensor. Eur 7 Obstet Gynecol Reprod Biol 1986;23:261-6.

(Accepted 2 March 1988)
University Department of Clinical Oncology, Newcastle General Hospital, Newcastle upon Tyne NE46BE

James Carmichael, MD, lecturer Brian M J Cantwell, MD, senior lecturer

Cathryn M Edwards, MA, medical student

Adrian L Harris, DPHIL, professor

Beecham Pharmaceuticals Research Division, Harlow, Essex

W Garth Rapeport, MRCP, clinical pharmacologist

Correspondence to: Professor Harris.

\section{The serotonin type 3 receptor antagonist BRL 43694 and nausea and vomiting induced by cisplatin}

\author{
James Carmichael, Brian M J Cantwell, \\ Cathryn M Edwards, W Garth Rapeport, \\ Adrian L Harris
}

In most patients receiving cisplatin nausea and vomiting are observed one to six hours after the drug is given and last for up to 10 days $^{1}$; currently available antiemetics show limited efficacy. At conventional doses metoclopramide is inactive, but at high doses it is effective against the vomiting induced by cisplatin, although extrapyramidal reactions are observed. ${ }^{2}$ At these doses metoclopramide competitively blocks serotonin type 3 receptors. ${ }^{3}$ Selective serotonin type 3 receptor antagonists exhibit potent antiemetic activity in ferrets and recently GR $38032 \mathrm{~F}$ was shown to be effective in patients receiving mildly emetic drugs, none of whom received cisplatin. ${ }^{4}$ We report the efficacy and tolerance of the new serotonin type 3 receptor antagonist BRL $43694^{5}$ in patients receiving cisplatin.

\section{Patients, methods, and results}

Cisplatin was given intravenously over 30 minutes, followed by BRL 43694 given by intravenous infusion in $250 \mathrm{ml} 0.9 \%$ saline over 30 minutes. The first five patients received concurrent dexamethasone $4 \mathrm{mg}$ four times a day, but as the infusions of BRL 43694 were noticeably effective BRL 43694 was subsequently infused on its own. After finishing treatment patients were hydrated for 24 hours. The number of episodes of vomiting and dry retching were recorded before the infusion and at one, four, six, eight, and 24 hours after it. In addition, severity of nausea was subjectively assessed with both global four point severity scores (before the infusion and at four and 24 hours after it) and $10 \mathrm{~cm}$ visual analogue scores (before the infusion and at one, four, and six hours after it), which were analysed with a paired Wilcoxon signed rank test.

Eighteen male and four female patients were studied (mean age $47 \cdot 4$ (SD 13) years), 13 of whom had

Details of treatment of 22 patients receiving BRL 43694 as antiemetic for control of nausea and vomiting induced by cisplatin

\begin{tabular}{|c|c|c|c|c|c|c|c|}
\hline \multirow{2}{*}{$\begin{array}{l}\text { Case } \\
\text { No }\end{array}$} & \multirow{2}{*}{$\begin{array}{c}\text { BRL } \\
43694 \\
(\mu \mathrm{g} / \mathrm{kg})\end{array}$} & \multirow{2}{*}{$\begin{array}{c}\text { Cisplatin } \\
\left(\mathrm{mg} / \mathrm{m}^{2}\right)\end{array}$} & \multirow[b]{2}{*}{ Other cytotoxics given } & \multicolumn{2}{|r|}{ Nausea } & \multirow{2}{*}{$\begin{array}{c}\text { No of } \\
\text { vomiting } \\
\text { episodes }\end{array}$} & \multirow{2}{*}{$\begin{array}{l}\text { Other } \\
\text { antiemetics } \\
\text { given }\end{array}$} \\
\hline & & & & Grade & Time of onset $(\mathrm{h})$ & & \\
\hline 1 & 10 & 50 & Bleomycin, methotrexate & 3 & 12 & 7 & Yes \\
\hline 2 & 10 & 50 & None & 4 & 4 & 6 & Yes \\
\hline $3^{\star}$ & 20 & 50 & Ifosfamide & 3 & 12 & None & Yes \\
\hline 4 & 20 & 50 & Doxorubicin & & None & None & No \\
\hline $5^{\star}$ & 20 & 60 & Hydroxyurea, bleomycin & & None & None & No \\
\hline $6^{\star}$ & 30 & 20 & Etoposide & & None & None & No \\
\hline 7 & 30 & 50 & Mitomycin & 2 & 12 & 3 & No \\
\hline $8^{\star}$ & 30 & 75 & None & & None & 5 & No \\
\hline $9 \star$ & 40 & 40 & Doxorubicin, hydroxyurea, bleomycin & & None & None & No \\
\hline $10^{\star}$ & 40 & 40 & Ifosfamide, vincristine & & None & None & No \\
\hline 11 & 40 & 50 & None & 2 & 6 & 1 & Yes \\
\hline $12^{\star}$ & 40 & 50 & None & 2 & 6 & 2 & Yes \\
\hline $13^{\star}$ & 40 & 60 & Doxorubicin, hydroxyurea, bleomycin & 3 & 12 & 5 & Yes \\
\hline $14^{\star}$ & 40 & 60 & Doxorubicin, hydroxyurea, bleomycin & & None & None & No \\
\hline 15 & 40 & 75 & None & 2 & 18 & 3 & Yes \\
\hline $16^{\star}$ & 40 & 75 & None & 4 & 4 & 2 & Yes \\
\hline 17 & 40 & 75 & None & & None & None & No \\
\hline $18^{\star}$ & 40 & 75 & None & & None & None & No \\
\hline $19^{\star}$ & 40 & 75 & Mitozantrone & & None & None & No \\
\hline $20^{\circ}$ & 40 & 75 & None & & None & None & No \\
\hline $21^{\star}$ & 40 & 75 & None & & None & None & No \\
\hline 22 & 40 & 100 & Fluorouracil & 2 & 16 & 2 & Yes \\
\hline
\end{tabular}

^Patient had previous chemotherapy. 
previously received chemotherapy. The table shows the details of their treatment. BRL 43694 was inactive at $10 \mu \mathrm{g} / \mathrm{kg}$, but at $20 \mu \mathrm{g} / \mathrm{kg}$ no vomiting was observed in three patients, although one patient felt nauseous. At $30 \mu \mathrm{g} / \mathrm{kg}$ nausea was considerably reduced, but breakthrough vomiting did occur in two out of three patients. In eight of the 14 patients treated with $40 \mu \mathrm{g} / \mathrm{kg}$ vomiting was prevented. Other antiemetic treatment was necessary for the six other patients, although the onset of vomiting was delayed in three patients beyond 12 hours. In the first six hours after receiving cisplatin only two patients vomited or experienced dry retching. Statistical analysis of the linear analogue scores for nausea showed no significant difference at one, four, and six hours after the infusion when compared with values before the infusion, and global rating scores showed that eight of the 14 patients had no nausea over 24 hours.

Intravenous administration of BRL 43694 was well tolerated in all patients with no toxic reactions. No clinically relevant changes in biochemical results or blood counts were observed, although one patient developed transient renal impairment; inadequate hydration after treatment with cisplatin was thought to be the causal factor. No important abnormalities in pulse rate, blood pressure, or cardiac rhythm were observed.

\section{Comment}

BRL 43694 was given to 22 patients receiving chemotherapy with cisplatin. Fourteen patients received the highest dose $(40 \mu \mathrm{g} / \mathrm{kg})$; eight of them had no nausea or vomiting, and in three of the remaining six the onset of nausea and vomiting was delayed beyond 12 hours. The drug was well tolerated, although headache lasting 36 hours was observed in one patient. Selective serotonin type 3 receptor antagonists would seem to have an important role in the control of emesis induced by chemotherapy. BRL 43694 at a dose of $40 \mu \mathrm{g} / \mathrm{kg}$ given as a single infusion for 30 minutes was safe and noticeably ameliorated nausea and vomiting in patients receiving doses of cisplatin ranging from 40 to $100 \mathrm{mg} / \mathrm{m}^{2}$.

1 Kris MG, Gralla RJ, Clark RA, et al. Incidence, course, and severity of delayed nausea and vomiting following the administration of high-dose cisplatinum. 7 Clin Oncol 1985;3:1379-84.

2 Bateman DN, Rawlins MD, Simpson JM. Extrapyramidal reactions with metoclopramide. BrMed f 1985;291:930-2.

3 Fozard JR, Mobarok Ali ATM. Blockade of neuronal tryptamine receptors by metoclopramide. Eur F Pharmacol 1978;49:109-12.

4 Cunningham D, Pople A, Ford HT, et al. Prevention of emesis in patients receiving cytotoxic drugs by GR $38032 \mathrm{~F}$, a selective $5-\mathrm{HT}_{3}$ receptor antagonist. Lancet $1987 ; \mathrm{i}: 1461-2$.

5 Zussman BD, Clarkeson A, Coates PE, Rapeport WG. The pharmacokinetic profile of BRL 43694, a novel 5- $\mathrm{HT}_{3}$ receptor antagonist, in healthy male volunteers. Br f Clin Pharmacol 1988;25:107P.

(Accepted 28 March 1988)

\section{Injuries caused by handcuffs}

\section{P W Richmond, L J Fligelstone, E Lewis}

Accident and Emergency Department, Cardiff Royal Infirmary, Cardiff P W Richmond, FRCS, senior registrar

L J Fligelstone, MB, senior house officer

E Lewis, MB, senior house officer

Correspondence to: Mr Richmond.
Compression of peripheral nerves around the wrist resulting from the use of handcuffs has been reported in the United States. The superficial branch of the radial nerve seems to be most commonly affected, ${ }^{1-4}$ but the median and ulnar nerves may be affected with both sensory and motor dysfunction. ${ }^{15}$

We found no reference to fractures of the radial styloid resulting from handcuffs and believe that the four cases we describe are the first reported instances of injury caused by handcuffs in the United Kingdom.

\section{Case reports}

Case 1-A 17 year old man, who had been detained in handcuffs for one to two hours two days previously, presented, with a tight pair of handcuffs around his wrists, with bilateral wrist pain and tenderness. Radiographs showed a fracture of the tip of the right radial styloid.

Case 2-A 24 year old man presented two days after being arrested, when his left wrist had been placed in handcuffs, resulting in immediate pain. Radiographs confirmed a fracture of the radial styloid process (figure). Two months later he was again arrested, and both wrists were placed in handcuffs, behind his back, for roughly 20 minutes. There was both subjective and objective loss of sensation on the dorsal aspect of both thumbs but no motor dysfunction, and parallel healing. abrasions were present over both wrists.

Case 3-A 17 year old man was detained for one to two hours in handcuffs. Initially he complained of numbness affecting the whole of the left hand, but the next day this was limited to the web space between thumb and index finger dorsally with associated objective loss of sensation but no motor dysfunction.

Case 4-A 25 year old man was seen 24 hours after he had been restrained in handcuffs with pain in the right hand and altered sensation affecting the palmar and dorsal aspects of the thumb and index and middle fingers and associated metacarpal regions, including the first dorsal web space, compatible with median and radial neuropathies. There was no motor dysfunction.

All four patients failed to attend follow up appointments.

\section{Comment}

The superficial branch of the radial nerve is purely sensory and at risk of pressure damage because of its superficial course over the lower end of the radius; it was affected in the patients in cases 2,3 , and 4 .

The median and ulnar nerves are also vulnerable to pressure as the adjacent flexor digitorum superficialis and flexor carpi ulnaris have become tendinous at this level, ${ }^{5}$ although venous stasis in the carpal tunnel may be a mechanism of median nerve compression. ${ }^{1}$ Multiple neuropathy from compression is rare, ${ }^{5}$ but both the median and radial nerves were affected in case 4 .

The standard handcuffs used by the police in Britain may be applied by flicking an open bar on to the detainee's wrist, allowing the cuff to spring shut on a

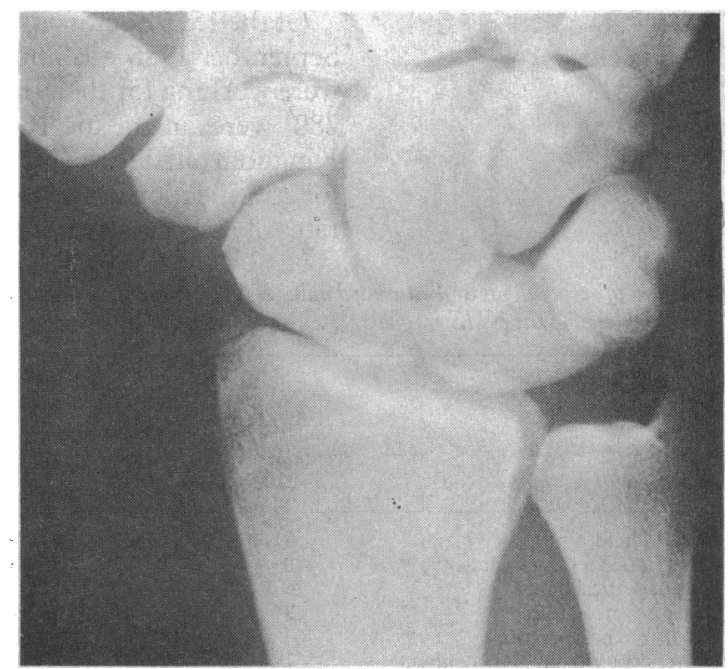

Case 2. Fractured tip of radial styloid 